There are two main issues for the conservation of gibbons on Borneo. Firstly, although the Bornean Hylobates muelleri and Bornean white-bearded Hylobates albibarbis gibbons are on the Indonesian protected species list, the northern gray Hylobates funereus and Abbott's gray Hylobates abbotti gibbons are not listed. Secondly, these four species occur mostly outside protected areas, on private and communityowned lands, and thus there needs to be multi-stakeholder engagement for the development of a conservation strategy.

To improve the conservation of Indonesia's gibbons, Perhimpunan Ahli dan Pemerhati Primata Indonesia, with the support of the Indonesian government, plans to design a policy brief and conduct a conservation planning workshop.

ARIF SETIAWAN (๑ orcid.org/0000-0002-6090-906X) and EKA CAHYANINGRUM (○ orcid.org/0000-0001-7850-9921)

SwaraOwa, Sleman, Yogyakarta, Indonesia

E-maila.setiawan@swaraowa.org

MARSYA CHRISTYANTI SibARANI (৫ orcid.org/0000-0003-0942139X) Tambora Muda Indonesia, Bogor, Indonesia

RAHAYU OKTAVIANI (○ orcid.org/0000-0002-8272-5245)

Javan Gibbon Research and Conservation Project, Bogor, Indonesia

IKE NURJUITA NAYASILANA (๖ orcid.org/0000-0001-9527-0449) Faculty of Agriculture, Universitas Sebelas Maret, Surakarta, Indonesia

Mohamad ARIF RIFoI Primate Research Centre, Universitas Nasional, Jakarta, Indonesia

AfRIzal MaUlana AbDi (৫ orcid.org/0000-0002-3185-3394) and ISMAIL AGUNG RUSMADIPRAJA (৫ orcid.org/0000-00015298-0010) Yayasan IAR Indonesia, Bogor, Indonesia

DIDIK PRASETYO (๑ orcid.org/0000-0001-5486-2624) Fakultas Biologi Universitas Nasional, Jakarta, Indonesia

This is an Open Access article, distributed under the terms of the Creative Commons Attribution licence CC BY 4.0.

\section{The roaming wild Asian elephants of Yunnan, China, pose a challenge to conservation}

In early 2020, 16 wild Asian elephants Elephas maximus, an iconic species of the tropical forest of South-east Asia and a First Category Key Protected Wild Animal Species in China, left the tropical forests of Xishuangbanna National Nature Reserve in Yunnan Province, on the China-Laos-Myanmar border, and headed northwards through a heavily modified anthropogenic landscape (see map below). The herd reached Pu'er City by March 2020, and Mojiang County by December 2020, where a calf was born. On 17 April 2021, the now 17 elephants reached Yuanjiang County, from where two of them returned to Mojiang County. In late April, these two elephants were still wandering in the Ning'er County of Pu'er City. By 27 May the herd of 15 elephants had reached Eshan County, only $120 \mathrm{~km}$ from Kunming City.

By the mid 2oth century the Asian elephant had been almost extirpated in China as large areas of tropical forest were logged. Most of the remaining elephants lived in the 24,000 km ${ }^{2}$ Xishuangbanna Reserve, established in 1986. In the early 1990s, these elephants, which had grown to a population of c. 300 , expanded their range northwards to Pu'er City, with some elephants settling in this hilly landscape interspersed with farmlands, tea gardens and secondary forests. Elephants from the Reserve are now apparently heading even further north, causing considerable disturbance as they journey. The wildlife management authority is monitoring the elephants with drones, where necessary warning local residents of the impending arrival of the herd. The herd has now moved a total of c. $500 \mathrm{~km}$ and is still on the move, reaching Jining District of Kunming City on 1 June.

Meanwhile, another herd, of 17 elephants, left the Mengyang area of Xishuanbanna Reserve and approached the Xishuanbanna Botanic Garden of the Chinese Academy of Sciences on 23 May 2021, where elephants were extirpated 70 years ago. These elephants are foraging in the part of the Garden used for ex situ conservation of rare crops. Part of the Garden has been closed and staff are monitoring the elephants with drones.

These two herds of Asian elephants pose a new challenge for conservation in China. In addition to investigating why elephants are leaving Xishuangbanna National Nature Reserve and to considering a new action plan for Asian elephant conservation in the country, we need to ensure the safety of people in the areas through which the elephants pass, and that of these roaming elephants.

ZHIGANG JIANG (๑ orcid.org/0000-0003-2154-8588) Institute of Zoology, and College of Life Science, University of Chinese Academy of Sciences, China. E-mail jiangzg@ioz.ac.cn

CHUNWANG LI (๑ orcid.org/0000-0002-1315-248X) Institute of Zoology, Chinese Academy of Sciences, China

Chenchen DING (৫ orcid.org/0000-0001-6706-7996) Beijing Normal University, China, and Institute of Zoology, Chinese Academy of Sciences, China

This is an Open Access article, distributed under the terms of the Creative Commons Attribution licence CC BY 4.0 . 


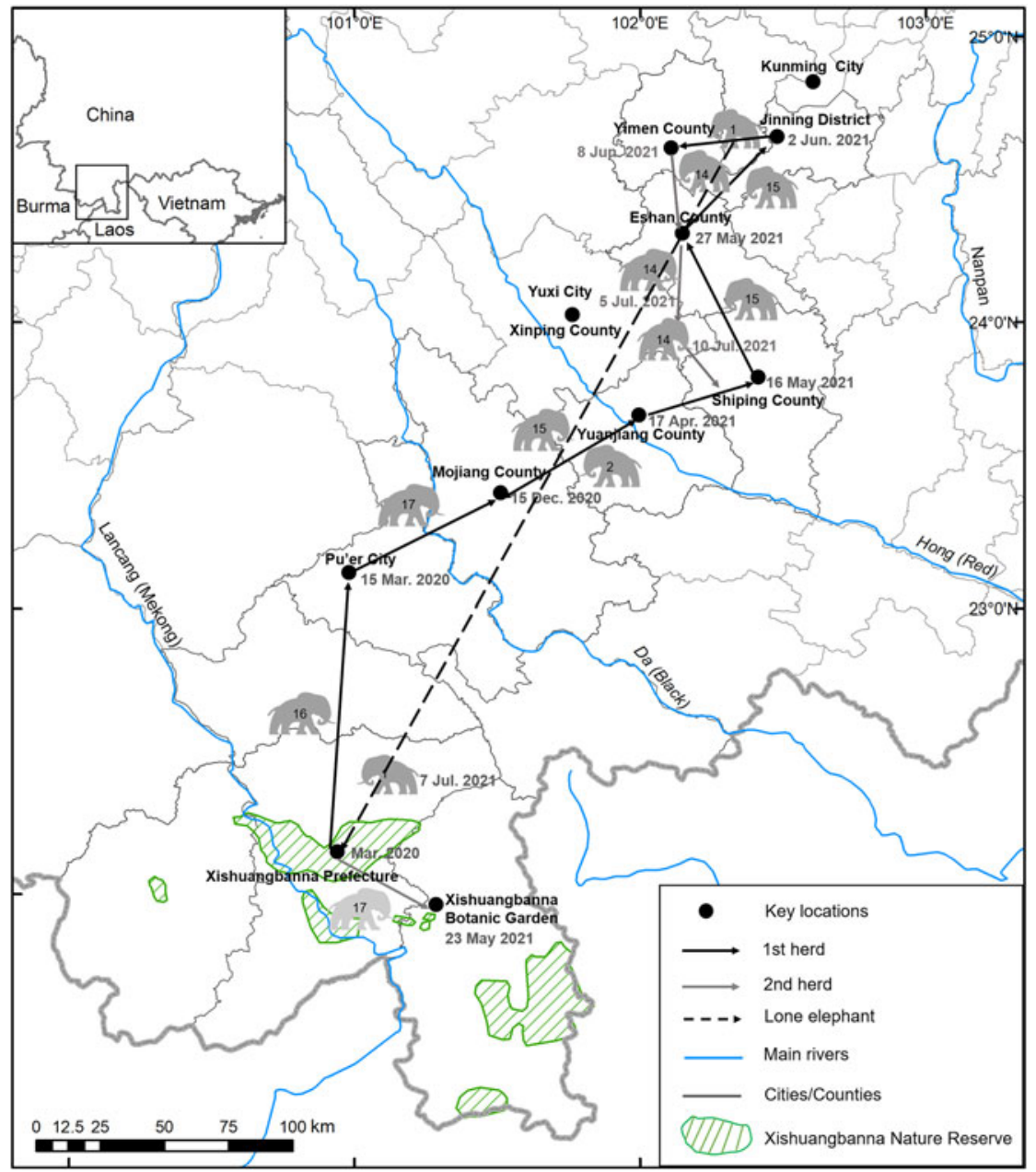

The movement paths of wild Asian elephants Elephas maximus from the Xishuangbanna National Nature Reserve to Kunming City and to Xishuanbanna Botanic Garden, Yunnan, China.

\section{IUCN launches Green Status of Species: a new standard for species recovery}

In summer 2021, IUCN launched the Green Status of Species, an optimistic new part of the Red List of Threatened Species that provides a tool for assessing species recovery and the impact of conservation. The Green Status of Species assesses three facets of recovery. A species is Fully Recovered (or Non-Depleted) if, in all parts of its indigenous range (areas that were occupied prior to major human impacts), it is (1) present, (2) viable (i.e. not threatened with extinction), and (3) ecologically functional.

These factors contribute towards a Green Score in the range 0-100\%, which shows how far a species is from its Fully Recovered state. This score is converted into recovery categories that mirror those of the Red List (e.g. Critically Depleted, Slightly Depleted). This definition of recovery is ambitious by design. It is not expected, nor is it a goal, that all species will eventually fulfil this definition of full recovery; for many species, large areas within their range have been irrevocably modified. Rather, this definition serves to standardize the assessment approach between species, and to identify areas of recovery opportunity in the context of what has been lost.
The Green Status of Species reports not only a species' current Green Score and corresponding recovery category, but also how conservation actions have affected the current status, what we might expect if conservation actions are halted, and how a species' status could improve in the future with conservation action. The past or potential impact of conservation action is captured in a set of conservation impact metrics, based on Green Scores calculated for different times and scenarios (Grace et al., 2021, Conservation Biology, dx.doi.org/10.1111/cobi.13756).

The Green Status of Species was developed following an IUCN Resolution that called for development of Green Lists of Species, Ecosystems and Protected Areas. The Green Status of Species therefore began development under the name Green List of Species (Akcakaya et al., 2018, Conservation Biology, 32, 1128-1138). Consultations during development indicated the name should be changed to Green Status of Species, to avoid the misconception that a species assessed on a Green List is no longer in need of conservation and any potential confusion with the IUCN Green List of Protected and Conserved Areas (Grace et al., 2021, Conservation and Society, in press).

For further information on the Green Status of Species, and to download a copy of the new Standard, see the IUCN Red 
List website (iucnredlist.org/about/green-status-species). Green Status of Species assessments will be published on the IUCN Red List website as they become available.

MOLLY K. GRACE (@ orcid.org/0000-0002-1978-615X) Department of Zoology, and Wadham College, University of Oxford, Oxford, UK. E-mail molly.grace@zoo.ox.ac.uk

ELIZABETH L. BENNETT Wildlife Conservation Society, New York, USA

H. REŞIT AKÇAKAYA (৫ orcid.org/0000-0002-8679-5929) Department of Ecology and Evolution, Stony Brook University, New York, USA

CRAig Hilton-TaYlor (@ orcid.org/0000-0003-1163-1425) IUCN, Cambridge, UK

Michael HoffMANN (๑ orcid.org/0000-0003-4785-2254) Zoological Society of London, London, UK

RichaRd JeNkINs IUCN Global Species Programme, Cambridge, UK

E.J. MilneR-Gulland (๑ orcid.org/0000-0003-0324-2710) Merton College, University of Oxford, Oxford, UK

ANA NIETO IUCN Global Species \& Key Biodiversity Areas Programme, Gland, Switzerland

RICHARD P. YOUNG (๑ orcid.org/0000-0002-6515-6343) Durrell Wildlife Conservation Trust, Jersey, British Channel Islands

BARNEY LONG (๑ orcid.org/0000-0002-9747-6042) Re:wild, Austin, USA

This is an Open Access article, distributed under the terms of the Creative Commons Attribution licence CC BY 4.0.

\section{A new breeding site of Hornby's storm petrel}

Hornby's storm petrel Oceanodroma hornbyi is a species endemic to the Humboldt Current Region of South America and one of the least known seabirds. Its population size is poorly documented, having been estimated in 2007 at 637,000-1,011,900 individuals, through open ocean counts (Spear \& Ainley, 2007, Ornithological Monographs, 62, 177). The species is categorized as Near Threatened on the IUCN Red List as the known area of its breeding colonies is small, and the species may be declining as a result of light pollution. In Chile, the species is categorized as Vulnerable, and its range includes northern coasts from the Tarapacá to the Atacama Regions.

The only known colony of Hornby's storm petrel is in Pampa de Indio Muerto in the Atacama Desert, Chile,

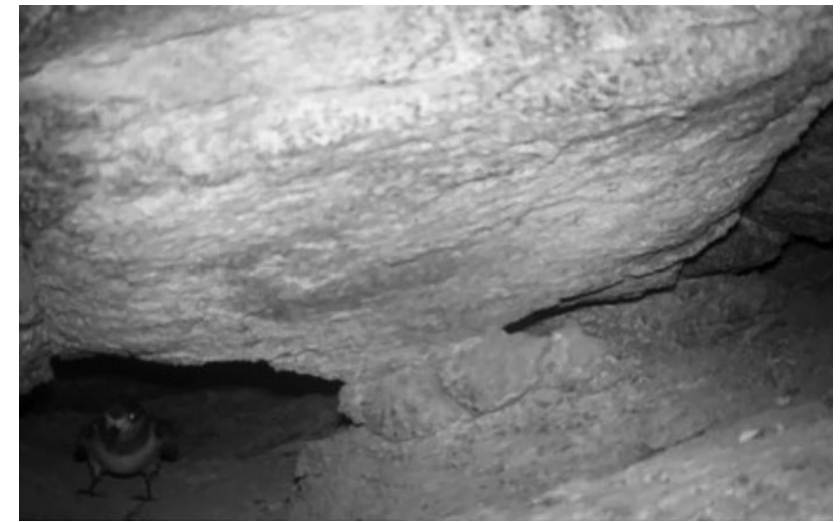

Hornby's storm petrel Oceanodroma hornbyi captured by a camera trap.

at $1,100 \mathrm{~m}, 75 \mathrm{~km}$ from the coast. Two breeding sites were recently reported in Chile: a single nest cavity at Salar de Quiuña, Tarapacá Region, and an individual leaving a cavity at Salar de Navidad, Antofagasta Region (Medrano et al., 2019, Revista Chilena de Ornitología, 25, 21-30). These breeding records are in natural shallow cavities in gypsum outcrops. Here, however, we describe the first record of Hornby's storm petrel breeding in a different environment.

On 13 February 2021, during research on rodents in a landscape dominated by abundant and steep rocky ravines with sparse vegetation, $12 \mathrm{~km}$ from the coast, at 1,050 m, c. $35 \mathrm{~km}$ south of Antofagasta, we recorded Hornby's storm petrel on a camera trap. The individual visited the nest, inside a small rocky cave, frequently, consistent with parental care. The main threats to the species in this area are loss and degradation of habitat and light pollution from mining, and solar and wind energy projects. In nearby areas we also recorded additional evidence of Hornby's storm petrel, in the form of feathers and faeces, suggesting a potential breeding colony.

RICARDo PINo RIFFo (๑ orcid.org/0000-0002-5510-9033)

Leopardus Austral Proyect, Santiago, Chile

E-mail r.pinovet@gmail.com

Marta Mora Espinoza (@ orcid.org/0000-0002-2821-0814) NGO Vida Nativa, Santiago, Chile

CRISTIAN SEPÚlVEDA CABRERA (@ orcid.org/0000-0002-18344472) Alianza Gato Andino, Santiago, Chile

This is an Open Access article, distributed under the terms of the Creative Commons Attribution licence CC BY 4.0.

\section{Illegal logging threatens to wipe out the Critically Endangered African zebrawood Microberlinia bisulcata from Cameroon's Ebo forest}

The African zebrawood Microberlinia bisulcata is a Critically Endangered species endemic to Cameroon. Demand for its 